\title{
Upaya Mengatasi Cekaman Kekeringan pada Tanaman Nilam (Pogostemon Cablin Benth.) dengan Memanfaatkan Kompos Kiambang
}

\section{(Resolving Drought Stress on Patchouli [Pogostemon $\underline{\text { cablin }}$ Benth.] Using Giant Salvinia Compost)}

\author{
Adryade Reshi Gusta ${ }^{1)^{*}}$, Any Kusumastuti ${ }^{1)}$ \\ 1) Jurusan Budidaya Tanaman Perkebunan, Politeknik Negeri Lampung, Jl. Soekarno-Hatta No. 10 \\ Rajabasa, Bandar Lampung, Telp.: (0721) 703995, Fax.: (0721) 787309 \\ E-mail: adryade@polinela.ac.id
}

\begin{abstract}
Productivity and quality of patchouli is influenced by environmental factors especially drought stress. This study aim is to determine application of giant salvinia compost for resolving drought stress on patchouli. This study used a randomized block design and experiment with three replication arranged in factorial $3 \times 4$. The first factor is percentage of drought stress $0 \%\left(L_{0}\right), 40 \%\left(L_{1}\right)$, and $80 \%\left(L_{2}\right)$. The second factor is application of giant salvinia compost, topsoil $100 \%\left(G_{0}\right)$, topsoil and giant salvinia compost 1:1 $\left(G_{1}\right)$, topsoil and giant salvinia compost 2:1 $\left(G_{2}\right)$, and topsoil and giant salvinia compost 3:1 $\left(G_{3}\right)$. The result showed that giant salvinia affected increasing on plant height, number of branch, the ratio of root-shoot dry weight, and patchouli oil content.
\end{abstract}

Keywords: growth medium, patchouli oil content, soil moisture

Diterima: 25 Juli 2017 / Disetujui: 2 Oktober 2017 / Diterbitkan: 22 Oktober 2017

\section{PENDAHULUAN}

Produktivitas tanaman dan mutu minyak nilam sangat dipengaruhi oleh faktor lingkungan terutama cekaman kekeringan.Selain memerlukan kelembapan optimal yang relatif tinggi, yaitu sekitar $60-90 \%$ untuk pertumbuhan tanaman yang optimum. Tanaman nilam mempunyai sistem perakaran yang dangkal sehingga rentan terhadap adanya cekaman kekeringan, terutama pada periode pertumbuhan awal. Cekaman kekeringan dapat menyebabkan transpor hara melalui akar tanaman mengalami gangguan yang ditandai dengan terjadinya perubahan warna daun menjadi kuning dan bila keadaan ini terjadi secara berkepanjangan, maka daun menjadi kering dan mati (Rosman et al., 1998).

Pada saat terjadi kekeringan, sebagian stomata daun menutup sehingga terjadi hambatan masuknya $\mathrm{CO}_{2}$ dan menurunnya aktivitas fotosintesis. Untuk mengantisipasi dampak buruk dari adanya cekaman kekeringan, diperlukan modifikasi teknik budidaya yang tepat dan penggunaan varietas atau klon unggul nilam yang toleran terhadap cekaman kekeringan. Penggunaan bahan organik merupakan salah satu teknik remediasi yang sering digunakan untuk perbaikan lahan kering. Jusuf (2008) dan Nasaruddin \& Rosmawati (2011) menyatakan bahwa pemberian bahan 
organik dalam bentuk kompos dapat memperbaiki kandungan kesuburan tanah maupun pertumbuhan tanaman semusim dan tahunan. Sampai saat ini informasi tentang ketahanan tanaman nilam terhadap cekaman kekeringan masih sangat terbatas sehingga diperlukan penelitian respons tanaman nilam terhadap cekaman air dan upaya perbaikan dengan menggunakan kompos kiambang. Penelitian ini bertujuan untuk menentukan dosis kompos kiambang yang tepat untuk mengatasi cekaman kekeringan pada nilam.

\section{METODE PENELITIAN}

Penelitian ini dilaksanakan di lingkungan Politeknik Negeri Lampung, mulai awal Mei sampai Oktober 2015. Bahan-bahan yang digunakan adalah setek nilam, topsoil, kompos kiambang, dan pestisida. Alat-alat yang digunakan adalah cangkul, drum air, polibeg, meteran, timbangan, kawat, handsprayer, ember plastik, dan alat-alat tulis. Penelitian ini menggunakan rancangan acak kelompok (RAK) berpola faktorial, yang terdiri atas 2 faktor yaitu kandungan lengas tanah (L) dan dosis kompos kiambang (G), yang diulang sebanyak 3 kali. Faktor pertama adalah kandungan lengas tanah yang dinyatakan dalam persen kapasitas lapangan yang terdiri atas tiga taraf, yaitu $40 \%$ kapasitas lapangan $\left(\mathrm{L}_{0}\right), 80 \%$ kapasitas lapangan $\left(\mathrm{L}_{1}\right)$, dan $100 \%$ kapasitas lapangan $\left(\mathrm{L}_{2}\right)$. Faktor kedua adalah perbandingan topsoil dan kompos kiambang $(\mathrm{v} / \mathrm{v})$, yang terdiri atas empat taraf, yaitu topsoil $100 \%\left(\mathrm{G}_{0}\right)$, top soil dan kompos kiambang dengan perbandingan 1:1 $\left(\mathrm{G}_{1}\right)$, topsoil dan kompos kiambang dengan perbandingan 2:1 $\left(\mathrm{G}_{2}\right)$, dan topsoil dan kompos kiambang dengan perbandingan 3:1 $\left(\mathrm{G}_{3}\right)$.

Perlakuan interval penyiraman dilakukan setelah tanaman nilam berumur 8 minggu setelah tanam (MST). Perubahan kadar lengas tanah dipantau dengan metode gravimetri dengan cara mengambil sampel tanah sebanyak $\pm 10 \mathrm{~g}$ pada polibeg yang berukuran $50 \mathrm{x} 40 \mathrm{~cm}$ sebelum penyiraman sehingga didapatkan kadar lengas tanah $100 \%$, 80\%, dan 40\%. Kapasitas air tersedia $(100 \%)$ dengan sejumlah 10 liter air.polibeg ${ }^{-1}$. Peubah yang diamati dalam percobaan ini meliputi: tinggi tanaman, jumlah cabang, bobot kering tajuk, bobot kering akar, dan rendemen minyak nilam. Pemanenan nilam dilakukan 18 minggu setelah tanam (MST). Seluruh data yang diperoleh dianalisis ragam. Analisis dilanjutkan dengan pemisahan nilai tengah menggunakan uji BNT dengan taraf nyata $5 \%$ jika hasil analisis ragam nyata.

\section{HASIL DAN PEMBAHASAN}

Berdasarkan hasil analisis ragam, cekaman kekeringan (kadar lengas tanah 40\%) menyebabkan penurunan pada tinggi tanaman, jumlah daun, jumlah cabang, bobot kering tajuk, bobot kering akar, dan rendemen (Tabel 1). Setiawan et al. (2013) mengemukakan bahwa pada kadar lengas tanah $20 \%$ menyebabkan tanaman nilam menjadi layu. Kandungan air tanah yang dikehendaki untuk pertumbuhan nilam adalah pada keadaan kapasitas lapang (100\% air tersedia). 
Lisar et al. (2012) menyatakan bahwa akibat cekaman kekeringan pada tanaman, yaitu penutupan stomata, penurunan laju fotosintesis dan laju transpirasi, penurunan laju penyerapan dan translokasi nutrien (unsur hara), penurunan pemanjangan sel, serta penghambatan pertumbuhan. Jika laju fotosintesis menurun, maka pertumbuhan tanaman juga akan terpengaruh karena berkurangnya sumber energi yang diperlukan untuk proses pembelahan dan pembesaran sel. Terhambatnya aktivitas pembelahan sel, menyebabkan tidak terjadinya penambahan massa atau isi sel dan pembentangan sel, sehingga sel-sel tetap mengecil (Chaves et al., 2003; Mapegau, 2006).

Tabel 1. Pengaruh media tanam dan cekaman air terhadap variabel tinggi tanaman, jumlah daun, jumlah cabang, bobot kering tajuk, bobot kering akar, dan rendemen pada 18 MST

\begin{tabular}{|c|c|c|c|c|c|}
\hline Perlakuan & $\begin{array}{c}\text { Tinggi } \\
\text { tanaman } \\
(\mathrm{cm})\end{array}$ & $\begin{array}{c}\text { Jumlah } \\
\text { cabang } \\
\text { (buah) }\end{array}$ & $\begin{array}{c}\text { Bobot } \\
\text { kering } \\
\text { tajuk } \\
(\mathrm{g})\end{array}$ & $\begin{array}{c}\text { Bobot } \\
\text { kering } \\
\text { akar } \\
(\mathrm{g})\end{array}$ & $\begin{array}{l}\text { Rendemen } \\
\text { minyak } \\
(\%)\end{array}$ \\
\hline \multicolumn{6}{|l|}{ Kadar lengas } \\
\hline $100 \%$ & $68,75 \mathrm{a}$ & 28,19 a & $38,05 \mathrm{a}$ & $5,25 \mathrm{a}$ & $0,66 \mathrm{a}$ \\
\hline $80 \%$ & $61,00 \mathrm{a}$ & $28,00 \mathrm{a}$ & $30,50 \mathrm{~b}$ & $2,75 \mathrm{~b}$ & $0,82 \mathrm{~b}$ \\
\hline $40 \%$ & $52,62 \mathrm{~b}$ & $24,00 \mathrm{~b}$ & $20,25 \mathrm{c}$ & $2,00 \mathrm{~b}$ & $1,02 \mathrm{c}$ \\
\hline \multicolumn{6}{|l|}{ Media tanam } \\
\hline Top soil $100 \%$ & $53,17 \mathrm{a}$ & $15,25 \mathrm{a}$ & 20,06 a & $2,33 \mathrm{a}$ & 0,76 \\
\hline Top soil : kompos kiambang $(3: 1)$ & $59,83 \mathrm{~b}$ & $24,66 \mathrm{~b}$ & $30,33 \mathrm{~b}$ & $4,67 \mathrm{~b}$ & 0,80 \\
\hline Top soil : kompos kiambang $(2: 1)$ & $63,58 \mathrm{c}$ & $32,00 \mathrm{c}$ & $32,56 \mathrm{~b}$ & $4,67 \mathrm{~b}$ & 0,82 \\
\hline Top soil : kompos kiambang $(1: 1)$ & $66,58 \mathrm{c}$ & $35,00 \mathrm{~d}$ & $42,00 \mathrm{c}$ & $5,00 \mathrm{~b}$ & 0,83 \\
\hline
\end{tabular}

Keterangan: Nilai tengah yang diikuti dengan huruf yang sama pada kolom yang sama menunjukkan tidak berbeda nyata menurut BNT pada taraf 5\%

Pemberian kompos kiambang mempengaruhi tinggi tanaman, jumlah daun, jumlah cabang, bobot kering tajuk, bobot kering akar, dan rendemen (Tabel 1). Pemberian pupuk organik seperti kompos kiambang ke dalam tanah dapat memperbaiki sifat fisik, kimia dan biologi tanah sehingga nutrisi tanaman menjadi efisien (Chenu et al., 2000). Kompos kiambang pada umumnya mengandung nitrogen. Kompos kiambang berasal dari adalah gulma kiambang (Salvinia natans) yang keberadaannya melimpah di permukaan waduk yang ada di Provinsi Lampung. Keberadan gulma ini dapat dimanfaatkan oleh petani untuk dibuat menjadi kompos dan dapat diaplikasikan sebagai media tanam (Hartono et al., 2014).

Penambahan kompos kiambang yang telah terdekomposisi pada media topsoil mampu meningkatkan hara di dalam tanah, selain itu kompos kiambang juga mampu memperahankan air tanah, sehingga tanaman yang diberi kompos menunjukkan pertumbuhan yang lebih baik. Selain itu, hasil penelitian Sinambariba et al.. (2013) menunjukkan bahwa dengan penambahan unsur nitrogen ke dalam tanah dapat merangsang jaringan meristematik yang semakin aktif membelah sehingga memacu pertumbuhan bibit khususnya tinggi tanaman, karena peran utama unsur $\mathrm{N}$ bagi tanaman adalah merangsang pertumbuhan tanaman khususnya batang, cabang, dan daun. 
Proses peningkatan bobot brangkasan (tajuk dan akar) yang optimal terjadi apabila tanaman memperoleh hara yang cukup sesuai dengan hara yang dibutuhkan akan memacu bertambahnya ukuran sel sehingga pertumbuhan tanaman dapat meningkat. Hasil ini sesuai dengan pendapat Indrawan et al. (2015) yang menyatakan bahwa pemberian kompos akan memperbaiki sifat fisik tanah yang menyebabkan tanah menjadi gembur.

Rendemen pada aras lengas tanah 100\% kapasitas lapang menunjukkan hasil tertinggi, sedangkan pada aras lengas tanah yang lebih rendah rendemen menunjukkan penurunan. Kusumastuti (2013) menyatakan bahwa pertumbuhan sangat peka terhadap cekaman air. Hasil panen akan menurun pada kekeringan sedang sampai berat.

\section{KESIMPULAN}

Cekaman kekeringan mulai kadar lengas tanah $40 \%$ mengakibatkan penurunan pada tinggi tanaman, jumlah daun, jumlah cabang, bobot kering tajuk, bobot kering akar, dan rendemen. Pemberian kompos kiambang mempengaruhi tinggi tanaman, jumlah daun, jumlah cabang bobot kering tajuk, bobot kering akar, dan rendemen minyak nilam.

\section{DAFTAR PUSTAKA}

Chaves, M. M., Maroco, J. P., \& Pereira, J. S. (2003). Understanding plant responses to drought: from genes to whole plant. Functional Plant Biology, 30, 239-264.

Chenu, C., Le Bissonnais, Y., \& Arronays, D. (2000). Organic matter influence on clay wettability and soil aggregate stability. Soil Science Society of America Journal, 64(4), 1479-1486.

Direktorat Jenderal Perkebunan. (2009). Statistik Perkebunan di Indonesia. Jakarta: Kementerian Pertanian.

Hartono, J. S. S., Same, M., \& Parapasan, Y. (2014). Peningkatan mutu kompos kiambang melalui aplikasi teknologi hayati dan kotoran ternak sapi. Jurnal Penelitian Pertanian Terapan, 14(3), $17-21$.

Indrawan, I., Kusumastuti, A., \& Utoyo, B. (2015). Pengaruh pemberian kompos kiambang dan pupuk majemuk pada pertumbuhan bibit kakao (Theobroma cacao L.). Jurnal Agro Industri Perkebunan, 3(1), 47-58.

Jusuf. (2008). Pengaruh lama pengomposan daun gamal terhadap pertumbuhan tanaman sawi. Jurnal Agrisistem, 4(1), 44-52.

Kusumastuti, A. (2013). Aktivitas mikroba tanah, pertumbuhan dan rendemen nilam (Pogostemon cablin Benth.) pada berbagai aras bahan organik serta lengas tanah di Ultisols. Jurnal Penelitian Pertanian Terapan, 13(2), 78-84.

Lisar, S. Y., Motafakkerazad, R., Hossain, M. M., \& Rahman, I. M. (2012). Water stress in plants: causes, effect and responses. In Water stress. InTech. 
Mapegau. (2006). Pengaruh Cekaman air terhadap pertumbuhan dan hasil tanaman kedelai. Jurnal Ilmiah Pertanian KULTURA, 41(1), 43-51.

Nasaruddin \& Rosmawati. (2011). Pengaruh pupuk organik cair (POC) hasil fermentasi daun gamal, batang pisang dan sabut kelapa tehadap pertumbuhan bibit kakao. Jurnal Agristem, 7(1), 29-37.

Setiawan, Tohari, \& Shiddieq, D. (2013). Pengaruh cekaman kurang air terhadap beberapa karakter fisiologis tanaman nilam (Pogostemon cablin Benth.). Jurnal Littri., 19(3), 108-116.

Rosman, Emmyzar, P., \& Wahid, P. (1998). Karakteristik lahan dan iklim untuk pewilayahan pengembangan. Dalam Monograf Nilam. Hal 47-55.

Sinambariba, A., Siagian, B., \& Silitonga, S. (2013). Respons pertumbuhan bibit kakao (Theobroma cacao L.) terhadap pemberian kompos blotong dan pupuk NPKMg pada media subsoil Ultisol. Jurnal Online Agroekologi, 1(3), 689-701. 